НАУКОВИЙ ВІСНИК

Entific messegeger of Lviv National University of

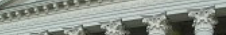

TIIII

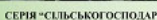

Том 22 №2 92

2020

Науковий вісник Яьвівського національного університету ветеринарної медицини та біотехнологій імені С.3. Гжицького. Серія: Сільськогосподарські науки

Scientific Messenger of Lviv National University of Veterinary Medicine and Biotechnologies. Series: Agricultural sciences

UDC [639.3.043:636.087.73]:639.371.52

\title{
Productivity and physiological-biochemical parameters of carp body after the supplementation of their feed with milk thistle
}

\author{
M. Korilyak \\ Institute of Fisheries NAAS, Kyiv, Ukraine
}

Article info

Received 20.02.2020 Received in revised form 23.03.2020 Accepted 24.03.2020

Institute of Fisheries of the National Academy of Agrarian Sciences of Ukraine, Obukhivska Str., 135, Kyiv, 03164, Ukraine.

Tel: $+38-067-370-11-92$

E-mail: stasiv8@gmail.com
Korilyak, M. (2020). Productivity and physiological-biochemical parameters of carp body after the supplementation of their feed with milk thistle. Scientific Messenger of Lviv National University of Veterinary Medicine and Biotechnologies. Series: Agricultural sciences, 22(92), $113-118$. doi: $10.32718 /$ nvlvet-a9219

The paper presents the results of studies of the effect of the milk thistle Silybum marianum feed supplement with biologically active properties on productive and some physiological and biochemical parameters of carp body. Three experiments were conducted during 2013-2014, each of which had a control group, which was fed with a basic diet, and three experimental groups, which received milk thistle seeds at concentrations of $1 \%, 5 \%$ and $10 \%$ in the diet, respectively. The object of the first experiment were age-1 carp, which were kept in aquariums and which received orally the ground seeds of the milk thistle in the composition of a starch paste (Control 1, Experiments 1-3). The object of the second and third experiments were age-1+ fish, which were fed with a feed supplemented with the milk thistle during the growing season (Control 2, Experiments 4-6 and Control 3, Experiments 7-9). The aim of the work was to determine the efficiency of the use of the milk thistle in carp feeding. At the same time, identical optimal conditions for keeping fish during testing were provided. The study was conducted according to conventional methods. The relative fat content in fish muscles was determined by the extraction method, total protein by the Kjeldahl method, and dry matter by evaporation. The hemoglobin content was determined by hemoglobin cyanide method, the number of erythrocytes was counted in the Goryaev's chamber. The obtained results were processed statistically, the difference between the groups was evaluated by the Student's test. After feeding age-1 carp with a feed supplemented with $5 \%$ ground seeds of the milk thistle, the hemoglobin contents increased in all experimental groups compared to the control and the number of erythrocytes. The relative fat content in the muscles of the experimental fish increased by $29.4 \%, 15 \%$ and $8.1 \%$, respectively, while the protein content did not change. Analysis of the results of studies on age-1+fish in 2013 showed an improvement in physiological parameters in all experimental groups compared to the control: hemoglobin content by $25.5(P<0.05), 12.5$ and $3.6 \%$; erythrocyte count - by 7.7, 8.5 and $2.7 \%$. The relative protein content in the muscles of carp fed with a feed supplemented with 1 and $5 \%$ milk thistle increased by $6.5 \%$ $(P<0.05)$ and $8.1 \%(P<0.05)$, fat - by 5.9 and $13.1 \%$, respectively. When feeding with $10 \%$ milk thistle, these values reduced by 4.5 and $10.8 \%$ compared to the control. Fish productivity in ponds, when fish was fed with 1 and $5 \%$ milk thistle was higher than in control by 26.1 and $28.2 \%$, the average weight of age-1+ by 21.6 and $23.8 \%$, while feed costs decreased by 1.4 times. A repeated similar experiment in 2014 showed that the hemoglobin content of fish fed with $1 \%$ milk thistle increased by $9 \%$, protein by $7.5 \%(P<0.001)$, dry matter by $6.9 \%(P<0.01)$. Fish culture parameters improved when supplementing fish feeds with 1 and $5 \%$ milk thistle: fish productivity in ponds increased by 44.9 and $31.3 \%$, the average fish weight increased by 33.8 and $20.1 \%$, the feed ratio was lower by 40.0 and $33.3 \%$ compared to the control group.

Key words: carp, milk thistle, feed additive, hematological parameters, chemical composition of muscles, length and weight parameters, survival, feed costs.

\section{Продуктивність та фізіолого-біохімічні показники організму коропа за введення до складу корму розторопші плямистої}

\author{
М. 3. Кориляк
}


Наведено результати досліджень впливу кормової добавки з біологічно активними властивостями розторопиі плямистої (Silybum marianum) на продуктивні та окремі фізіолого-біохімічні показники організму коропа. Проведено три експерименти впродовж 2013-2014 років, в кожному з яких була контрольна група, яка отримувала основний раціон, і три дослідні з використанням розторопші плямистої в кількості відповідно 1 \%, 5 \% і 10 \% у складі рачіону. Об'єктом першого експерименту були однорічки коропа, яких утримували в умовах акваріумів $і$ оральним способом вводили у складі крохмального клейстеру розмелене насіння розторопмі плямистої (контроль 1, досліди 1-3). Об'єктом другого і третього експериментів були дволітки, яким розторопиу плямисту вводили до складу корму $і$ згодовували впродовж вегетаційного періоду (контроль 2, досліди 4-6 та контроль 3, досліди 7-9). Метою роботи було визначення ефективності використання розторопші плямистої в годівлі коропа. При иьому забезпечено ідентичні оптимальні умови утримання риб при постановці випробувань. Рибницькі дослідження проведено за загальноприйнятими методиками. У м'язах коропів визначали відносний вміст жиру екстракційним методом, загального білка - методом К'єльдаля. Вміст гемоглобіну в крові коропів визначали гемоглобінціанідним методом, кількість еритроцитів підраховували у камері Горяєва. Одержані результати опрацьовували статистично, різницю між групами оцінювали за критерієм Стьюдента. За введення меленого насіння розторопші однорічкам коропа виявлено тенденцію до зростання вмісту гемоглобіну в крові усіх дослідних груп щзодо контролю та кількості еритроцитів за додавання 5 \% розторопиі. У м'язах риб дослідних збільшився відносний вміст жиру відповідно на 29,4\%, 15 \% і 8,1\%, при цььому вміст протеїну практично не змінився. Аналіз результатів досліджень введення розторопші до складу раціону дволіток у 2013 роиі свідчить про покращення фізіологічних показників в усіх дослідних групах щцодо контрольної: вмісту гемоглобіну відповідно на 25,5 (P < 0,05), 12,5 та 3,6 \%; кількості еритроцитів - на 7,7, 8,5 та 2,7\%. Відносний вміст протеїну у м'язах коропів за згодовування 1 і $5 \%$ розторопші зріс відповідно на 6,5\% (P < 0,05) та 8,1\% $(P<0,05)$, жиру - на 5,9 і 13,1\%. За згодовування $10 \%$ розторопші дані показники знижуються на 4,5 $і$ 10,8 \% щздо контролю. Рибопродуктивність у ставах за згодовування 1 i 5\% розторопші була вищзю щзодо контролю на 26,1 $i$ 28,2 \%, середня маса дволіток на 21,6 i 23,8 \%, при иььому витрати корму на приріст зменшились в 1,4 разу. Повторний аналогічний експеримент 2014 року свідчить, щзо вміст гемоглобіну у крові риб, яким згодовували 1 \% розторопші, зріс на $9 \%$, протеїну - на 7,5 \% $(P<0,001)$, сухої речовини на 6,9\% (P < 0,01). Рибогосподарські показники поліпшилися за згодовування 1 i $5 \%$ насіння розторопші: рибопродуктивність у ставах зросла на 44,9 і 31,3\%, середня маса риб збільшилась на 33,8 і 20,1\%, кормовий коефіцієнт був нижчим на 40 і 33,3\% щцодо показників контрольної групи.

Ключові слова: короп, розторопша плямиста, кормова добавка, гематологічні показники, хімічний склад м'язів, розмірновагові показники, виживаність, витрати кормів.

\section{Вступ}

Інтенсифікація виробництва є невід'ємною частиною ефективного ведення рибогосподарської діяльності. Це передбачає збільшення густоти посадки риб та впровадження нормованої годівлі в процесі вирощування, що призводить до підвищення навантаження на екосистему (Hrynzhevskyi et al., 2007). Окрім того, в умовах сьогодення погіршення екологічного стану водойм в результаті промислової діяльності призводить до розвитку інфекційних захворювань, зниження розчиненого у воді кисню та деградації водних екосистем (Yalynska et al., 2011; Shved et al., 2013). В peзультаті екзогенне та ендогенне навантаження негативно впливає на стан систем організму риб, зокрема резистентність, що призводить до зниження темпів росту, розвитку захворювань чи навіть загибелі риб (Vishchur et al., 2008). Це зумовлено впливом цих чинників на низку фізіологічних функцій i різних ланок обміну речовин в їхньому організмі (Yanovych \& Yanovych, 2014).

В сучасних умовах особливо актуальною $\epsilon$ проблема дефіциту високопоживних і легкоперетравних компонентів корму, що призводить до зниження продуктивних та репродуктивних показників, збільшення витрат кормів та собівартості продукції тваринництва. Збалансована годівля риб відповідно до фізіологічних потреб організму, а також додаткове збагачення раціону кормовими добавками 3 біологічно активними властивостями забезпечують реалізацію завдання отримання генетично обумовлених приростів 3 найменшими економічними затратами (Hrytsyniak et al., 2008; Korobov \& Moskalenko, 2014; Coffey et al., 2016).
Більшість кормових добавок впливає лише на окремі фізіолого-біохімічні показники організму риб, не справляючи комплексного стимулюючого впливу на організм. Однією 3 добавок широкого спектру дії рослинного походження $\epsilon$ розторопша плямиста (Silybum marianum), яку використовують в тваринництві як стимулятор росту і репродуктивної системи, імуномодулятор, а також засіб, що поліпшує засвоєння поживних речовин. Також розторопша містить діючу речовину силімарин, що забезпечує ії гепатопротекторну дію (Koryliak, 2013). Насіння розторопші плямистої містить близько 200 компонентів широкого спектру дії. Завдяки унікальному набору $\omega-3$ поліненасичених жирних кислот в оптимальному співвідношенні розмелене насіння розторопші добре впливає на обмін речовин, підвищує опірність організму до захворювань, володіє антиалергенними і детоксикаційними властивостями. Виявлена його антиоксидантна, антимутагенна, мембранопротекторна, ранозагоювальна дії. Крім лікувальних властивостей, розторопша має харчову цінність: в розмелених плодах розторопші міститься 14,32 \% протеїну, 20,22 \% жиру, $30,53 \%$ клітковини (Pradhan \& Girish, 2006; Kolesnyk et al., 2007). Крім того, додавання розторопші плямистої до складу раціону тварин сприяє підвищенню приростів, продуктивності та рівня виживання (Kurylo \& Kondratiuk, 2016).

Попередньо нами отримані позитивні напрацювання використання розторопші плямистої в годівлі коропа (Koryliak et al., 2017; 2019).

Дослідження в годівлі головного об'єкта аквакультури України - коропа (Cyprinus carpio L.) нового кормового компонента, а саме розторопші плямистої, яка характеризується високим вмістом біологічно активних речовин, а відповідно широким спектром 
впливу на органи та системи організму, є актуальним завданням для забезпечення оптимального рівня функціонального стану організму та підвищення рибогосподарських показників в процесі вирощування коропа.

Метою роботи було дослідження доцільності та ефективності застосування розторопші плямистої в процесі вирощування коропа відповідно до спектра біологічних характеристик, $з$ огляду на продуктивні та фізіолого-біохімічні показники організму.

Оцінка ефективності включала комплексне визначення рибогосподарських, гематологічних та біохімічних показників. Використання традиційних та сучасних методів досліджень дає можливість оцінювати стан організму на різних його рівнях.

\section{Матеріал і методи досліджень}

Дослідження проведено в умовах лабораторних та польових умовах Львівської дослідної станції Інституту рибного господарства НААН смт Великий Любінь Городоцького району Львівської області впродовж 2013-2014 років і включало три серії з метою встановлення оптимальної кількості введення розторопші плямистої до складу кормів для коропа, виходячи 3 літературних даних щодо рекомендованих норм іiі застосування в тваринництві.

На першому етапі досліджень проведено серію лабораторних випробувань. 3 цією метою сформовано 4 групи риб по 10 екз в кожній. Об’єктом дослідження були однорічки любінського коропа середньою масою 42 г, які утримувались в лотках ємністю 150 л. Контрольній групі (К1) орально вводили $3 \%$ крохмальний клейстер один раз на добу з розрахунку $3 \%$ від маси тіла риб. В дослідних групах додатково до крохмального клейстеру введено розмелені плоди розторопші плямистої в кількості 1 \% (Д1), 5 \% (Д2) і $10 \%$ (Д3). Дослід тривав 12 днів. При цьому здійснювали аерацію води, забезпечували оптимальні показники температурного та кисневого режимів, а також основних хімічних показників водного середовища.

3 метою проведення другого етапу досліджень, у 2013 році зарибнено чотири стави-аналоги зі спільним джерелом водопостачання площею 0,14-0,19 га однорічками любінського коропа середньою масою 43 г за густоти посадки 1000 екз/га. Годівля контрольної групи (К2) риб здійснювалась кормом без добавок. Дослідним групам риб додатково до складу раціону методом гранулювання введено розмелені плоди розторопші плямистої в кількості 1 \% (Д4), 5 \% (Д5) і 10 \% (Д6) впродовж всього вегетаційного періоду.

У 2014 році проведено аналогічний до попереднього етап. Сформовано контрольну (К3) та три дослідні групи (Д7, Д8, Д9) середньою масою 55 г. Розторопшу вводили до складу раціону методом гранулювання впродовж 60 днів.

До складу основного раціону дволіток коропа входили, \%: зерно пшениці - 58, кукурудза - 20, голозерний овес -20 , рибне борошно - 2. Всього у дослідженнях використано 40 особин однорічок і 1300 особин дволіток коропа.
По закінченні експериментальних робіт здійснено оцінку впливу додавання до комбікорму розторопші на рибогосподарські (приріст маси, виживаність та витрати кормів на вирощування) i фізіологобіохімічні (поживність м'яса і гематологічні) показники організму експериментальних груп риб.

Визначали відсоток виходу риби з вирощування, іiі загальну і середню масу, коефіцієнт вгодованості (за Фультоном) та відбирали проби для проведення фізіолого-біохімічних досліджень (Zheltov, 2003).

Досліджували хімічний склад м'язів за традиційними методиками. Масову частку білка визначали за методом К'єльдаля, вміст жиру - за методом С. В. Рушковського, за кількістю знежиреного залишку в апараті Сокслета при використанні бензолу як розчинника, вміст сухої речовини - випаровуванням при температурі $100-105^{\circ} \mathrm{C}$ до постійної маси протягом 3-5 год (Lebedev \& Usovich, 1976).

Вміст гемоглобіну в крові коропів визначали гемоглобін-ціанідним методом (з ацетоннінгідрином). Принцип методу полягає в тому, що гемоглобін при взаємодії з залізосиньородистим калієм окиснюється в метгемоглобін, який утворює 3 ацетонціангідрином забарвлений гемоглобінціанід, інтенсивність якого пропорційна вмісту гемоглобіну (Derviz \& Vorob'ev, 1969). Кількість еритроцитів у крові коропів підраховували в камері Горяєва (Ivanova, 1983).

Одержані цифрові результати опрацьовували статистично за допомогою стандартного пакету статистичних програм Microsoft EXCEL. Вираховували середні арифметичні величини (М), середню квадратичну помилку (m) і вірогідність різниць (Р) між досліджуваними середньоарифметичними величинами (Plokhinskiy, 1961). Різницю між групами оцінювали за критерієм Стьюдента і вважали вірогідною при значеннях: * $-\mathrm{P}<0,05 ; * *-\mathrm{P}<0,01 ; * * *-\mathrm{P}<0,001$.

\section{Результати та їх обговорення}

При розробці та теоретичному обгрунтуванні норм уведення до складу комбікорму для коропа варто оцінювати не тільки продуктивні показники, а й картину крові, оскільки вона найоб'єктивніше характеризує важливі процеси життєдіяльності організму (Volichenko et al., 2015).

При оральному введенні 1 \% мелених плодів розторопші плямистої однорічкам коропа в складі крохмального клейстеру гематологічні показники знизилися щодо показників контрольної групи, зокрема вміст гемоглобіну і кількість еритроцитів мали тенденцію до зниження відповідно на 10,4 \% і 9,4 \% (рис. 1). При введенні 5 і $10 \%$ розторопші вміст гемоглобіну зріс відповідно на 18,0 \% і 11,9 \%, кількість еритроцитів на 8,6 \% і 0,9\%. Одержані результати свідчать про те, що найбільш виражений позитивний вплив на фізіологічні показники крові однорічок коропів справляє введення розмелених плодів розторопші плямистої в кількості $5 \%$.

При аналізі фізіолого-біохімічних показників експериментальних груп дволіток коропа першої повторності встановлено, що вміст гемоглобіну у крові риб за введення $1 \%$ розторопші плямистої був вірогідно 
вищий щодо контрольної, а саме на 25,5 \% (P < 0,05). За введення 5 і $10 \%$ - мав тенденцію до збільшення відповідно на 12,5 та 3,6 \%. Кількість еритроцитів в усіх дослідних групах риб зростала щодо контрольної відповідно на 7,7 \%, 8,5 \% та 2,7\%.

Дані гематологічних досліджень дволіток коропа другої повторності показали, що вміст гемоглобіну зріс за згодовування 1 і $5 \%$ розторопші відповідно на 9 та 7,2 \% порівняно 3 контрольною групою. Показ- ники кількості еритроцитів в крові усіх груп риб та вмісту гемоглобіну за введення $10 \%$ розторопші практично не відрізнялися від контрольних.

Поживну цінність і харчові властивості риби характеризує хімічний склад м'яса, який істотно залежить не тільки від іiі виду та фізіологічного стану організму, а й від віку, статі, сезону, годівлі, водойми та інших умов навколишнього середовища (Sherman \& Yevtushenko, 2011).

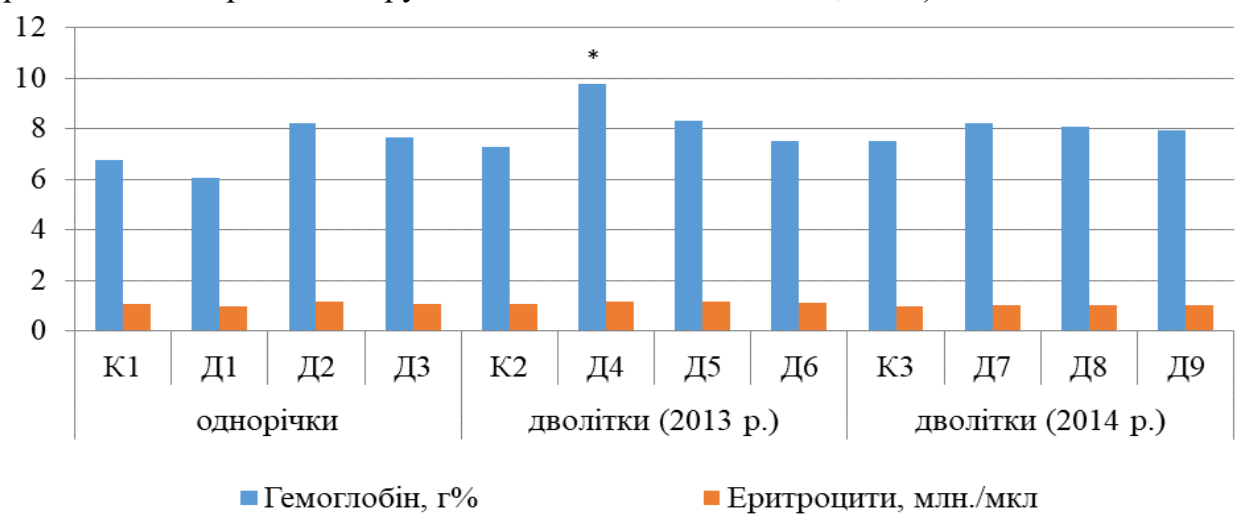

Рис. 1. Фізіологічні показники крові коропа за згодовування розторопші плямистої $(\mathrm{M} \pm \mathrm{m}, \mathrm{n}=3)$ Примітка: вірогідність різниці між контрольними (К1, К2 і К3) і дослідними (Д1 - Д3, Д4 - Д6, Д7 - Д9, відповідно) групами: * $-\mathrm{P}<0,05 ; * *-\mathrm{P}<0,01 ; * * *-\mathrm{P}<0,001$

Відносний вміст сирого протеїну в м’язах однорічок коропів дослідних груп був нижчим щодо контрольної групи на 1-4 \% з найменшим показником за введення 1 \% розторопші (рис. 2). Вміст сухої речовини дещо зріс за введення 1 і $10 \%$ розторопші. Відносний вміст жиру мав тенденцію до зростання в м'язах усіх дослідних груп щодо контрольної відповідно на 29,4 \%, 15 \% і 8,1 \%. Відносний вміст жиру у м'язах коропів після зимівлі є критично низьким i набув значень 1,13-1,60\%, введення розторопші плямистої сприяло зростанню даного показника за оптимальної кількості $1 \%$.

Вміст протеїну в м'язах дволіток коропа, яким до основного раціону додавали 1 і 5 \% розмелених плодів розторопші плямистої, був вірогідно більшим, ніж в контролі, відповідно на 6,5\% $(\mathrm{P}<0,05)$ та 8,1 \%
( $>$ < 0,05), а введенні $10 \%$ розторопші - нижчим на 4,5 \%. Така ж тенденція визначена і за вмістом жиру у м'язовій тканині, що відповідно зріс на 5,9 \% і 13,1 \% та знизився на 10,8 \% порівняно з показниками контрольної групи. Відповідно до показників відносного вмісту протеїну і жиру в м'язах дослідних груп, вміст сухої речовини теж зростає $(\mathrm{P}<0,05)$ за згодовування 1 і $5 \%$ і зменшується $(\mathrm{P}<0,01)$ за згодовування $10 \%$ розторопші.

Аналізуючи отримані результати другої повторності годівлі дволіток, можна зробити висновок, що вміст протеїну за введення $1 \%$ розторопші був на $7,5 \%$ більшим $(\mathrm{P}<0,01)$, ніж у контролі, відповідно вміст сухої речовини зріс на $6,9 \%$ (Р < 0,001). Вміст жиру в м'язовій тканині у всіх дослідних групах був у межах від 3,90 до 4,03 \%.

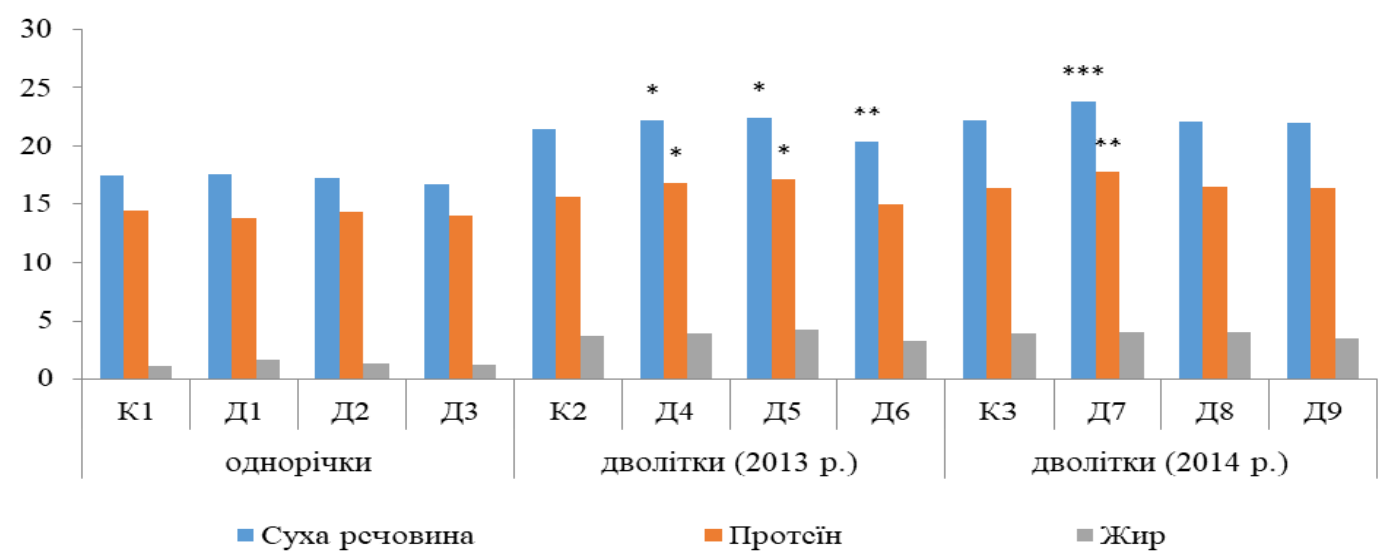

Рис. 2. Хімічний склад мязів різновікових груп коропа за введення до складу раціону розторопші плямистої $(\mathrm{M} \pm \mathrm{m}, \mathrm{n}=3)$

Примітка: вірогідність різниці між контрольними (К1, К2 і К3) і дослідними (Д1 - Д3, Д4 - Д6, Д7 - Д9, відповідно) групами: * - $\mathrm{P}<0,05 ; * *-\mathrm{P}<0,01 ; * * *-\mathrm{P}<0,001$ 
Після облову ставів першої повторності встановлено, що середня маса коропів дослідних груп, яким до складу корму було введено $1 \%$ і 5 \% меленого насіння розторопші плямистої були вищими щодо контрольної групи відповідно на 21,6 і 23,8 \%, рибопродуктивність при цьому збільшилась на 26,1 і $28,2 \%$ (табл. 1). Кормовий коефіцієнт в даних варіантах досліду був в 1,4 разу нижчим щодо контролю. За згодовування $10 \%$ розторопші в складі корму середня маса коропів при вилові зменшилась на 8,5 \%, відповідно рибопродуктивність знизилась на 11,9 \% порів- няно 3 контролем. При цьому витрати кормів на вирощування та виживаність риб не відрізнялись від показників контрольної групи.

Схожі результати отримано у другій повторності: рибопродуктивність дослідних ставів за згодовування 1, 5 і $10 \%$ розторопші була вищою відповідно на 31 , 23,8 і 3,6 \% порівняно з контролем (табл. 1). Введення 1 і $5 \%$ розторопші до складу раціону сприяло зростанню середньої маси дволіток при вилові на 25,3 і 16,8 \%, при цьому кормовий коефіцієнт був нижчим в 1,7 та 1,5 разу.

\section{Таблиця 1}

Результати вирощування дволіток коропа за додавання до основного раціону розторопші плямистої

\begin{tabular}{|c|c|c|c|c|c|c|c|c|c|c|}
\hline \multirow[b]{2}{*}{ Група риб } & \multicolumn{3}{|c|}{ Посаджено } & \multicolumn{4}{|c|}{ Виловлено } & \multirow{2}{*}{$\begin{array}{l}\text { Рибо- } \\
\text { прод., } \\
\text { кг/га }\end{array}$} & \multicolumn{2}{|c|}{ Згодовано корму } \\
\hline & $\begin{array}{l}\text { к-ть, } \\
\text { екз. }\end{array}$ & $\begin{array}{c}\text { cep. } \\
\text { маса, г }\end{array}$ & $\begin{array}{c}\text { заг. } \\
\text { маса, кг }\end{array}$ & вихід, \% & $\begin{array}{r}\text { к-ть, } \\
\text { екз. }\end{array}$ & $\begin{array}{c}\text { cep. } \\
\text { маса, Г }\end{array}$ & $\begin{array}{c}\text { заг. } \\
\text { маса, кг }\end{array}$ & & кг & од. \\
\hline Контроль 2 & 170 & 43 & 7 & 85 & 145 & 414 & 60 & 311 & 391 & 6.4 \\
\hline Дослід 4 & 140 & 43 & 6 & 88 & 123 & 528 & 65 & 421 & 293 & 4,5 \\
\hline Дослід 5 & 150 & 43 & 7 & 86 & 129 & 543 & 72 & 433 & 319 & 4,4 \\
\hline Дослід 6 & 190 & 42 & 8 & 85 & 161 & 379 & 61 & 274 & 397 & 6,5 \\
\hline Контроль 3 & 170 & 57 & 10 & 80 & 136 & 432,0 & 58,7 & 345 & 265 & 4,5 \\
\hline Дослід 7 & 140 & 57 & 8 & 87 & 122 & 578,0 & 70,5 & 500 & 193 & 2,7 \\
\hline Дослід 8 & 150 & 53 & 8 & 87 & 131 & 519,0 & 68,0 & 453 & 205 & 3,0 \\
\hline Дослід 9 & 190 & 53 & 10 & 82 & 156 & 435,8 & 68,0 & 358 & 281 & 4,1 \\
\hline
\end{tabular}

Отже, оптимальним є введення до складу раціону коропа розмеленого насіння розторопші плямистої в кількості 1 \% у складі раціону з огляду на результати досліджуваних показників.

\section{Висновки}

Встановлено підвищення продуктивності рибогосподарських водойм та поліпшення низки фізіолого-біохімічних показників коропів шляхом введення до складу основного раціону розторопші плямистої.

Виявлено тенденцію до зростання вмісту гемоглобіну в усіх дослідних варіантах щодо контрольного 3 найвищими за введення однорічкам $5 \%$ розторопші, дволіткам $1 \%(\mathrm{P}<0,05)$, кількості еритроцитів за введення $5 \%$ розторопші.

У м'язах однорічок дослідних збільшився відносний вміст жиру відповідно на 29,4 \%, $15 \%$ i $8,1 \%$, при цьому вміст протеїну практично не змінився. Відносний вміст протеїну у м'язах дволіток коропа за згодовування 1 i $5 \%$ розторопші, зріс відповідно на 6,5 \% $(\mathrm{P}<0,05)-7,5 \%(\mathrm{P}<0,001)$ та $8,1 \%$ ( $<$ < 0,05), жиру - на 5,9 і $13,1 \%$. За згодовування $10 \%$ отримано зниження даних показників.

Рибопродуктивність у ставах за згодовування 1 i $5 \%$ розторопші в кінці вегетаційного сезону була вищою щодо контролю на 26,1-44,9 \% і 28,2-31,3\%, середня маса дволіток на 21,6-33,8 \% і 23,8-20,1\%, при цьому витрати корму на приріст зменшились в $1,1-1,7$ разу.

Впровадження поставленого завдання забезпечило можливість підвищення рибопродуктивності ставів за рахунок згодовування штучних кормів поліпшеного складу. Зниження собівартості та отримання додаткових приростів при вирощуванні рибної продукції забезпечено удосконаленням якісних характеристик корму та відповідно фізіологічних показників організму дволіток коропа.

\section{References}

Coffey, D., Dawson, K., Ferket, P., \& Connolly, A. (2016). Review of the feed industry from a historical perspective and implications for its future. Journal of Applied Animal Nutrition. 4. 1-11. doi: 10.1017/jan.2015.11.

Derviz, G. V., \& Vorob'ev, A. I. (1969). Kolichestvennoe opredelenie gemoglobina krovi posredstvom apparata FEK. Laboratornoe delo, 4, 2-8 (in Russian).

Hrynzhevskyi, M. V., Yaninovych, Y. Ye., \& Shvets, T. M. (2007). Efektyvnist intensyfikatsii stavovoho rybnytstva v suchasnykh umovakh. Rybohospodarska nauka Ukrainy, 2, 34-40. http://nbuv.gov.ua/UJRN/ rnu_2007_2_9 (in Ukrainian).

Hrytsyniak, I. I., Hrynzhevskyi, M. V., Tretiak, O. M., Kiva, M. S., \& Mruk A. I. (2008). Fermerske rybnytstvo. Kyiv: Herb. (in Ukrainian).

Ivanova, N. T. (1974). Metodika nekotorykh gematologicheskikh pokazateley $u$ ryb. Tipovye metodiki issledovaniy produkivnosti vidov ryb $\mathrm{v}$ predelakh ikh arealov : sb. nauchn. tr. Vil'nyus, 83-90 (in Russian).

Kolesnyk, M. D., Semenov, S. O., Bankovska, I. B., \& Trotskyi, M. Ya. (2007). Osoblyvosti khimichnoho skladu roztoropshi pliamystoi. Visnyk Poltavskoi derzhavnoi ahrarnoi akademii. 1. 93-95 (in Ukrainian). 
Korobov, A. P., \& Moskalenko, S. P. (2014). Nauchnoobosnovannye normy kormleniya sel'skokhozyaystvennykh zhivotnykh: kratkiy kurs lektsiy. Saratov: Saratovskiy GAU (in Russian).

Koryliak, M. Z. (2013). Fitoterapevtychni vlastyvosti roztoropshi pliamystoi ta yii vykorystannia $\mathrm{v}$ hodivli tvaryn. Rybohospodarska nauka Ukrainy, 4, 97-108. http://nbuv.gov.ua/UJRN/rnu_2013_4_12 (in Ukrainian).

Koryliak, M. Z. (2019). Rezultaty vyroshchuvannia tovarnoho koropa (Cyprinus Carpio Linnaeus, 1758) pry vykorystanni $\mathrm{v}$ skladi ratsionu roztoropshi pliamystoi (Silybum marianum (L.) Geartn). Rybohospodarska nauka Ukrainy, 4(50), 109-122. doi: 10.15407/fsu2019.04.109 (in Ukrainian).

Koryliak, M. Z., Hrytsyniak, I. I., Deren, O. V., \& Dobrianska, O. P. (2017). Perebih okysnykh protsesiv $\mathrm{v}$ hepatopankreasi dvolitok koropa za vvedennia do skladu kormiv roztoropshi pliamystoi (Silybum marianum L.). Rybohospodarska nauka Ukrainy, 1, 73-83. doi: 10.15407/fsu2017.01.073 (in Ukrainian).

Koryliak, M. Z., Vishchur, O. I., \& Hrytsyniak, I. I. (2019). Vplyv roztoropshi pliamystoi (Silybum marianum) na stan $\mathrm{T}$ - i V-klitynnoho imunitetu ta pryrodnu rezystentnist dvolitok koropa. Rybohospodarska nauka Ukrainy, 3(49), 89-100. doi: 10.15407/fsu2019.03.089 (in Ukrainian).

Kurylo, V., \& Kondratiuk, S. (2016). Roztoropsha pliamysta u humannii i veterynarnii medytsyni. Tvarynnytstvo Ukrainy, 1-2, 38-40. http://nbuv.gov.ua/UJRN/TvUkr_2016_1-2_13 (in Ukrainian).

Lebedev, P. T., \& Usovich, A. T. (1976). Metody issledovaniya kormov, organov i tkaney zhivotnykh. Moskva: Rossel'khozizdat (in Russian).

Plokhinskiy, H. A. (1969). Rukovodstvo po biometrii dlya zootekhnikov. Moskva: Kolos (in Russian).

Pradhan, S. C., \& Girish, C. (2006). Hepatoprotective herbal drug, silymarin from experimental pharmacology to clinical medicine. Indian. J. Med. Res., 124(5), 491-504. https://pubmed.ncbi.nlm.nih.gov/17213517.
Sherman, I. M., \& Yevtushenko, M. Yu. (2011). Teoretychni osnovy rybnytstva : pidruch. Kyiv (in Ukrainian).

Shved, O. M., Petrina, R. O., Chervetsova, V. H., Hubrii, Z. V., Stadnytska, N. Ye., \& Novikov, V. P. (2013). Biomonitorynh ekolohichnoho stanu pryrodnykh poverkhnevykh vodnykh obiektiv Lvivskoi oblasti. Visnyk Natsionalnoho universytetu "Lvivska politekhnika". Khimiia, tekhnolohiia rechovyn ta yikh zastosuvannia, 761, 114-119. http://nbuv.gov.ua/ UJRN/VNULPX_2013_761_28 (in Ukrainian).

Vishchur, O. I., Kychun, I. V., Leshovska, N. M., Mamchuk, N. A., Yamroz, V. Y., Matlakh, I. Y., \& Rokyta, I. M. (2008). Pryrodna rezystentnist deiakykh vydiv ryb. Nauk.-tekhn. biul. In-tu biolohii tvaryn ta Derzh. n.-d. kontrol. in-tu vetpreparativ ta korm. Dobavok, 9(3), 343-347 (in Ukrainian).

Volichenko, Yu. M., Pentyliuk, S. I., \& Sherman, I. M. (2015). Hematolohichni pokaznyky krovi tsoholitok koropovykh (Cyprinidae) ryb, vyroshchenykh za pasovyshchnoiu tekhnolohiieiu $\mathrm{v}$ umovakh pivdnia Ukrainy. Rybohospodarska nauka Ukrainy, 4, 90-99. http://nbuv.gov.ua/UJRN/rnu_2015_4_9 (in Ukrainian).

Yalynska, Y., Andrushchyshyn, O., Dumych, O., \& Savytska, O. (2011). Zbizhnist znachen, yaki kharakteryzuiut funktsionalnu aktyvnist zooplanktonu i zabrudnennia. Visnyk Lvivskoho un-tu. Seriia biolohichna, 56, 157-163. http://publications.lnu.edu.ua/ bulletins/index.php/biology/article/view/8829 (in Ukrainian).

Yanovych, N. Ye., \& Yanovych, D. O. (2014). Rol mikroelementiv u zhyttiediialnosti stavkovykh ryb. Naukovyi visnyk LNUVMBT imeni S. Z. Hzhytskoho, 16, 345-372. http://nbuv.gov.ua/UJRN/nvlnu 2014_16_2\%282\%29_58 (in Ukrainian).

Zheltov, Yu. O. (2003). Metodychni vkazivky z provedennia doslidiv po hodivli ryb. Rybne hospodarstvo, 62, 23-28 (in Ukrainian). 